\title{
SOLUTION STUDY OF TERNARY COMPLEXES OF NICKEL(II) CONTAINING HISTIDINE AND DIOLS
}

\author{
ANWAR A. GESAWAT', MUSA A. AHMED' AND FAIYAZ SHAKEEL *2

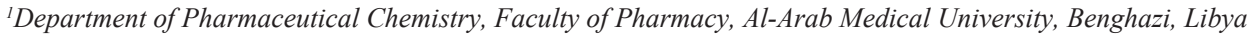 \\ ${ }^{2}$ Department of Pharmaceutics, Faculty of Pharmacy, Al-Arab Medical University, Benghazi, Libya
}

(Received: May 15, 2009 - Accepted: July 21, 2010)

\begin{abstract}
The stability constants of the mixed ligand ternary complexes of nickel(II) of the type MAB, MA ${ }_{2}$ and MAB, (where $\mathrm{A}=$ histidine, $\mathrm{B}=$ diols, viz. ethane diol, propane-1,2-diol, butan-1,3-diol, 2-butene-1,4-diol, pentane-2,4-diol and hexane-1,6-diol) were determined by potentiometric method. The difference in the stability constants of binary and ternary complexes $(\Delta \log K)$ and total enhancement of stability due to mixed ligand complex formation $(\log \mathrm{X})$ were of greater magnitude in $\mathrm{MA}_{2} \mathrm{~B}$ systems than those in $\mathrm{MAB}_{2}$ systems. This appeared to be due to the greater number of nitrogen atoms coordinating to metal ion in the $\mathrm{MA}_{2} \mathrm{~B}$ species. Some changes in the stability constants have been found to be due to the variation in the size of the ring formed by diols. The stability of 2-Butene-1,4-diol containing species exhibited the highest stability in this series. It was concluded that the $\pi$-system of the ligands is important for such a great increase in stability.
\end{abstract}

Keywords: Solution study; ternary complexes; stability constant; nickel(II); histidine, diols.

\section{INTRODUCTION}

During the recent years a systematic study has been done for the synthesis, stability constant and magnetic studies of some mixed ligand complexes of nickel(II) ${ }^{1-5}$ The synthesis of these complexes mainly involved the interaction of metal ion with amino acid L-histidine as a primary ligand while various diols acted as secondary ligands. Recently there has been considerable interest in the mixed chelation because it occurs commonly in biological fluids, which contain millions of potential ligands which are likely to compete for metal ions, found in vivo. ${ }^{2,4}$ It is well known that the ternary coordination complexes play an important role in biological processes like as an exemplified many instances in which enzymes are known to be activated by metal ions. ${ }^{2}$ Ternary complexes have also been implicated in the storage and transport of active substances through membranes and thus phenomenon like these are to be strongly dependent on the formation of these species and the electronic configuration of metal ion concerned.

Mixed chelation as defined here is the coordination of the same metal ion by at least one amino acid (A) and a bidentate ligand diol(B). ${ }^{3}$ The definitive properties of the mixed ligand chelates are in its composition, the atoms which are bounded to metal ion, its structure and degree of protonation. Siegel et al (1975) have observed an increase in the stability of the ternary complexes if the ligand contained a hetero atom nitrogen base (basic character) and an oxygen donor ligand. ${ }^{6}$

In the present research work we investigated the system containing histidine (pseudo-aromatic system) with $\mathrm{N}$-as donor site and diols with oxygen as donor atom. We have observed the greater stability of complexes containing two histidene and one glycol as compared to complex with one histidene and two glycols. As the stability of binary complexes is strongly dependent upon size of chelate ring. ${ }^{7}$ The same may be surmised for the mixed ligand ternary complexes, specially where one ligand is aromatic. ${ }^{8}$

\section{EXPERIMENTAL}

\section{Materials}

L-Histidine monohydrochloride and various diols were purchased from Fluka chemicals A.G. (Mumbai, India). The diols were purified by distillation under reduced pressure. Nickel(II) chloride six hydrate and $\mathrm{KNO}_{3}$ were of B.D.H. grade (Mumbai, India).

\section{Synthesis of the ternary complexes}

To the aqueous solution of nickel(II) chloride 6-hydrate $(0.01 \mathrm{M})$, aqueous solutions of histidine $(0.01,0.01$ or $0.02 \mathrm{M})$ and diols $(0.01,0.02$ or $0.01 \mathrm{M})$ were added simultaneously. The reaction mixture was well stirred in nitrogen atmosphere and a standard solution of lithium hydroxide was then added to maintain $\mathrm{pH}$ around 7 . The turbidity due to lithium chloride was removed by filtration and the solution was concentrated on water bath. The crystalline product obtained after keeping the concentrated solution in a vacuum desiccator was washed with methanol and dried in vacuum. ${ }^{4}$

\section{Physical measurements}

Nickel(II) and nitrogen were estimated by ethylene diamine tetra acetic acid complexometric titration ${ }^{5}$ and micro kjeldehl method respectively. ${ }^{9-10}$ The magnetic moment of the complexes was determined at $293 \pm 0.5 \mathrm{~K}$ on Gouy magnetic balance in solution. The electronic spectra of these complexes were recorded in aqueous solution by Carl Zeiss Jena Spectrophotometer (Carl Zeiss Promenade, Jena, Germany). These spectra were used for the calculation of various spectral parameters ${ }^{10}$ viz. interelectronic repulsion parameter (B), crystal field splitting energy (Dq), nephelauxetic ratio $(\beta)$ and the ratio $\mathrm{Dq} / \mathrm{B}$.

The stability constants $\beta_{\mathrm{MAB}}, \beta_{\mathrm{MAB} 2}$ and $\beta_{\mathrm{MA} 2 \mathrm{~B}}$ of the ternary complexes were calculated from the data obtained from alkalimetric titrations $\left(\mathrm{I}=0.2, \mathrm{KNO}_{3} ; 30\right.$ ${ }^{\circ} \mathrm{C}$ ) of the solution containing nickel(II) $(0.005 \mathrm{M})$, histidine $(0.005 \mathrm{M})$ and diol $(0.005 \mathrm{M})$ in the molar ratios $1: 1,1: 2,1: 3,1: 1: 1,1: 1: 2$ and $1: 2: 1$ by taking into account the formation of the species MA, $\mathrm{MA}_{2}, \mathrm{MA}_{3} \mathrm{MB}, \mathrm{MB}_{2}, \mathrm{MB}_{3} \mathrm{MAB}$, $\mathrm{MA}_{2} \mathrm{~B}, \mathrm{MAB}_{2}{ }^{9-11}$ The stability constants of the binary $(1: 1,1: 2,1: 3)$ complexes were calculated and used for the calculation of $\beta_{\mathrm{MAB}}, \beta_{\mathrm{MAB} 2}$ and $\beta_{\mathrm{MA} 2 \mathrm{~B}}{ }^{12}$

\section{RESULTS AND DISCUSSION}

The analytical data and magnetic moments of ternary complex of nickel(II) are shown in Table 1 . The stability constants of the ternary complexes MAB, $\mathrm{MAB}_{2}$ and $\mathrm{MA}_{2} \mathrm{~B}$ type species are defined by equations 1 to 6 .

$$
\begin{array}{lll}
\mathrm{M}+\mathrm{A}+\mathrm{B}=======\mathrm{MAB} ; \beta_{\mathrm{MAB}}= & {[\mathrm{MAB}] /[\mathrm{M}][\mathrm{A}][\mathrm{B}]} \\
\mathrm{M}+\mathrm{A}+2 \mathrm{~B}=======\mathrm{MAB}_{2} ; \beta_{\mathrm{MAB} 2}= & {\left[\mathrm{MAB}_{2}\right] /[\mathrm{M}][\mathrm{A}][\mathrm{B}]^{2}} \\
\mathrm{M}+2 \mathrm{~A}+\mathrm{B}======\mathrm{MA}_{2} \mathrm{~B} ; \beta_{\mathrm{MA} 2 \mathrm{~B}}= & {\left[\mathrm{MA}_{2} \mathrm{~B}\right] /[\mathrm{M}][\mathrm{A}]^{2}[\mathrm{~B}]} \\
\mathrm{MA}+\mathrm{B}======\mathrm{MAB} ; \quad \mathrm{K}_{\mathrm{MAB}}= & {[\mathrm{MAB}] /[\mathrm{MA}][\mathrm{B}]} \\
\mathrm{MA}+2 \mathrm{~B}======\mathrm{MAB}_{2} ; \mathrm{K}_{\mathrm{MAB} 2}= & {\left[\mathrm{MAB}_{2}\right] /[\mathrm{MA}][\mathrm{B}]^{2}} \\
\mathrm{MB}+2 \mathrm{~A}======\mathrm{MA}_{2} \mathrm{~B} ; \mathrm{K}_{\mathrm{MA} 2 \mathrm{~B}}= & {\left[\mathrm{MA}_{2} \mathrm{~B}\right] /[\mathrm{MB}][\mathrm{A}]^{2}}
\end{array}
$$

The overall stability constants $\beta_{\mathrm{MAB}} \beta_{\mathrm{MAB} 2}$ and $\beta_{\mathrm{MA} 2 \mathrm{~B}}$ are also connected with stability constants of binary as well as ternary complexes. This may be shown below (eq. 7-9)

$$
\begin{aligned}
& \log \mathrm{K}_{\mathrm{MAB}}=\log \beta_{\mathrm{MAB}}-\log \mathrm{K}_{\mathrm{MA}} \\
& \log \mathrm{K}_{\mathrm{MAB} 2}=\log \beta_{\mathrm{MAB} 2}-\log \mathrm{K}_{\mathrm{MA}} \\
& \log \mathrm{K}_{\mathrm{MA} 2 \mathrm{~B}}=\log \beta_{\mathrm{MA} 2 \mathrm{~B}}-\log \mathrm{K}_{\mathrm{MB}}
\end{aligned}
$$

The total enhancement of stability due to mixed complex formation may express in terms of $\log X$ parameter $^{13}$ (eq.10-12).

$$
\begin{aligned}
& \log \mathrm{X}_{\mathrm{MAB}}=2 \log \beta_{\mathrm{MAB}}-\left(\log \beta_{\mathrm{MA} 2}+\log \beta_{\mathrm{MB} 2}\right) \\
& =\left(_{\log }-\mathrm{M}_{\mathrm{MAB}}-\log \mathrm{K}_{\mathrm{MB} 2}\right)+\left(\log \mathrm{K}_{\mathrm{MAB}}-\log \mathrm{K}_{\mathrm{MA} 2}\right) \\
& \log \mathrm{X}_{\mathrm{MAB} 2}=3 \log \beta_{\mathrm{MAB2}}-\left(\log \beta_{\mathrm{MA} 3}+2 \log \beta_{\mathrm{MB}}\right) \\
& =\left(\log \mathrm{K}_{\mathrm{MAB} 2}-\log \mathrm{K}_{\mathrm{MA}}\right)+2\left(\log \mathrm{M}_{\mathrm{MAB} 2}-\log \mathrm{K}_{\mathrm{MB}}\right) \\
& \log \mathrm{X}_{\mathrm{MA} 2 \mathrm{~B}}=3 \log \beta_{\mathrm{MA} 2 \mathrm{~B}}-\left(2 \log \beta_{\mathrm{MA3}}+\log \beta_{\mathrm{MB} 3}\right) \\
& =2\left(\log \mathrm{K}_{\mathrm{MA} 2 \mathrm{~B}}-\log \mathrm{K}_{\mathrm{MA} 3}\right)+\left(\log \mathrm{K}_{\mathrm{MA} 2 \mathrm{~B}}-\log \mathrm{K}_{\mathrm{MB} 3}\right)
\end{aligned}
$$


Table 1 Analytical data and magnetic moment of ternary complexes of nickel(II) of the type $\mathrm{MAB}(*), \mathrm{MAB}_{2}(\#)$, and $\mathrm{MA}{ }_{2} \mathrm{~B}(\mathrm{x})[\mathrm{M}=\mathrm{Nickel} \mathrm{A}=\mathrm{Histidine}, \mathrm{B}=$ Diols at $293 \pm 0.5 \mathrm{~K}$

\begin{tabular}{|c|c|c|c|c|c|c|c|c|c|c|}
\hline Ligand (B) & Mol. Wt. & \multicolumn{2}{|c|}{$\begin{array}{c}\% \text { Nickel } \\
\text { Calc. Found }\end{array}$} & \multicolumn{2}{|c|}{$\begin{array}{l}\% \text { Nitrogen } \\
\text { Calc. Found }\end{array}$} & \multicolumn{2}{|c|}{$\begin{array}{l}\% \text { Carbon } \\
\text { Calc. Found }\end{array}$} & \multicolumn{2}{|c|}{$\begin{array}{l}\text { \% Hydrogen } \\
\text { Calc. Found }\end{array}$} & \multirow{2}{*}{$\begin{array}{c}\begin{array}{c}\text { Magnetic } \\
\text { moment } \\
\text { ( } \boldsymbol{\mu}) \text { (B.M.) }\end{array} \\
3.46 \\
3.45 \\
3.46\end{array}$} \\
\hline Ethane-diol & $\begin{array}{l}311.7 * \\
337.7 \# \\
430.7 \mathbf{x}\end{array}$ & $\begin{array}{l}18.8 \\
17.3 \\
13.6\end{array}$ & $\begin{array}{l}18.8 \\
17.4 \\
13.6\end{array}$ & $\begin{array}{l}13.4 \\
12.4 \\
19.5\end{array}$ & $\begin{array}{l}13.5 \\
12.4 \\
19.4\end{array}$ & $\begin{array}{l}30.8 \\
35.5 \\
39.0\end{array}$ & $\begin{array}{l}30.8 \\
35.5 \\
39.0\end{array}$ & $\begin{array}{l}5.4 \\
5.6 \\
4.6\end{array}$ & $\begin{array}{l}5.5 \\
5.6 \\
4.7\end{array}$ & \\
\hline Prop-1,2-diol & $\begin{array}{l}325.6^{*} \\
365.6 \# \\
444.5 \mathbf{x}\end{array}$ & $\begin{array}{l}18.0 \\
16.0 \\
13.2\end{array}$ & $\begin{array}{l}18.1 \\
16.0 \\
13.1\end{array}$ & $\begin{array}{l}12.9 \\
11.4 \\
18.9\end{array}$ & $\begin{array}{l}12.8 \\
11.4 \\
18.8\end{array}$ & $\begin{array}{l}33.1 \\
39.3 \\
40.4\end{array}$ & $\begin{array}{l}33.2 \\
39.4 \\
40.5\end{array}$ & $\begin{array}{l}5.8 \\
6.2 \\
4.9\end{array}$ & $\begin{array}{l}5.8 \\
6.3 \\
5.0\end{array}$ & $\begin{array}{l}3.48 \\
3.46 \\
3.43\end{array}$ \\
\hline 2-Butene-1,4-diol & $\begin{array}{c}337.5^{*} \\
389.6 \# \\
456.8 \mathbf{x}\end{array}$ & $\begin{array}{l}17.3 \\
15.0 \\
12.8\end{array}$ & $\begin{array}{l}17.4 \\
15.1 \\
12.9\end{array}$ & $\begin{array}{l}12.4 \\
10.7 \\
18.3\end{array}$ & $\begin{array}{l}12.5 \\
10.8 \\
18.4\end{array}$ & $\begin{array}{l}35.5 \\
43.1 \\
42.0\end{array}$ & $\begin{array}{l}35.5 \\
43.0 \\
42.0\end{array}$ & $\begin{array}{l}5.6 \\
5.9 \\
4.8\end{array}$ & $\begin{array}{l}5.6 \\
5.9 \\
4.9\end{array}$ & $\begin{array}{l}3.41 \\
3.46 \\
3.43\end{array}$ \\
\hline But1,3-diol & $\begin{array}{l}339.7 * \\
393.5 \# \\
458.7 \mathbf{x}\end{array}$ & $\begin{array}{l}17.2 \\
14.9 \\
12.7\end{array}$ & $\begin{array}{l}17.2 \\
14.9 \\
12.8\end{array}$ & $\begin{array}{l}12.3 \\
10.6 \\
18.3\end{array}$ & $\begin{array}{l}12.3 \\
18.6 \\
10.3\end{array}$ & $\begin{array}{l}35.3 \\
42.6 \\
41.8\end{array}$ & $\begin{array}{l}35.3 \\
42.6 \\
41.9\end{array}$ & $\begin{array}{l}6.1 \\
6.8 \\
5.2\end{array}$ & $\begin{array}{l}6.2 \\
6.9 \\
5.1\end{array}$ & $\begin{array}{l}3.47 \\
3.46 \\
3.41\end{array}$ \\
\hline Pent-2,4-diol & $\begin{array}{l}353.8^{*} \\
421.8 \# \\
472.6 \mathbf{x}\end{array}$ & $\begin{array}{l}16.5 \\
13.9 \\
12.4\end{array}$ & $\begin{array}{l}16.5 \\
13.8 \\
12.4\end{array}$ & $\begin{array}{r}11.9 \\
9.9 \\
17.7\end{array}$ & $\begin{array}{c}11.9 \\
10.0 \\
17.8\end{array}$ & $\begin{array}{l}37.3 \\
45.5 \\
43.1\end{array}$ & $\begin{array}{l}37.2 \\
45.5 \\
43.2\end{array}$ & $\begin{array}{l}6.5 \\
7.3 \\
5.5\end{array}$ & $\begin{array}{l}6.5 \\
7.3 \\
5.6\end{array}$ & $\begin{array}{l}3.47 \\
3.49 \\
3.47\end{array}$ \\
\hline Hex-1,6-diol & $\begin{array}{l}367.7 * \\
449.7 \# \\
486.6 \mathbf{x}\end{array}$ & $\begin{array}{l}15.9 \\
13.0 \\
12.0\end{array}$ & $\begin{array}{l}15.9 \\
13.1 \\
12.0\end{array}$ & $\begin{array}{c}11.4 \\
9.3 \\
17.2\end{array}$ & $\begin{array}{c}11.3 \\
9.0 \\
17.2\end{array}$ & $\begin{array}{l}39.1 \\
48.0 \\
44.3\end{array}$ & $\begin{array}{l}39.1 \\
48.0 \\
44.4\end{array}$ & $\begin{array}{l}6.8 \\
7.7 \\
5.7\end{array}$ & $\begin{array}{l}6.7 \\
7.8 \\
5.8\end{array}$ & $\begin{array}{l}3.44 \\
3.48 \\
3.47\end{array}$ \\
\hline
\end{tabular}

The participation of a particular functional group in the metal binding depends upon two factors. How successfully does the functional group compete against others in vicinity? And how successfully do the metal ions compete against the protons for the potential donor atoms? Part of first question lies in the acid dissociation constant ( $\mathrm{pK}$ ) of the functional group. The lower the $\mathrm{pK}$ greater is the availability of the donor atoms for the formation of the metal ligand bond. According to this criterion, the order of metal-legand binding tendencies will be carboxyl $>$ imidazole $>$ amino $\left[\mathrm{pK}_{\mathrm{acOOH}}=1.8, \mathrm{pK}_{\mathrm{almH}}^{+}=6.5, \mathrm{pK}_{\mathrm{aNH} 2}{ }^{+}=9.0\right]$. It is however risky to use this criterion alone because the order of pKa values may not be same as that of enthalpy changes accompanying complex formation. Secondly the nature of metal ion and its softness \& hardness will also contribute significantly in choosing particular co-ordinating site of the ligand. $\mathrm{pH}$ of solutions was maintained at around 8.0 for the preparation of ternary complex of $\mathrm{Ni}^{2+}$ because more stable complex formation was achieved (unpublished data). Secondary acidbase reactions were also considered at $\mathrm{pH}$ of 8.0 because of more stable complex formation by $\mathrm{Ni}^{2+}$. In these complexes it was observed that mixed ligand ternary complexes have more stability than corresponding binary complexes which obey the primitively stated rule. Martin and Paris (1963) \& Siegel et al (1976) stated that complexes containing a hetero aromatic nitrogen base and an oxygen as a donor ligand have high stability. ${ }^{12-13}$ This most probably was due to the evaporative effects and $\pi$-bond formation in the system. Griesser and Siegel(1970) showed that complexes containing nitrogen atom as a donor have more stability and higher value of $\Delta \log \mathrm{K}$ and $\log \mathrm{X}$ than those with oxygen as a donor atom. ${ }^{14}$ Irving et al (1954) expressed that stability of binary chelate complexes is strongly dependent upon the size of the ring but not of their side chain, basicity of the ligands and thus same may be surmised for the mixed ligand complexes.

All the complexes of the type $\mathrm{MA}_{2} \mathrm{~B}$ have more nitrogen bonding atoms, more basicity and aromatic character due to imidazole moiety than of $\mathrm{MAB}_{2}$ type. Thus $\mathrm{MA}_{2} \mathrm{~B}$ type complexes should be more stable than of the $\mathrm{MAB}_{2}$ system. All these facts are satisfied for these complexes as shown in Table 2 as the values of $\Delta \log \mathrm{K}$ and $\log \mathrm{X}$ are higher in case of MA $\mathrm{B}$ type (Table 3). In case of butene diol, stability is observed highest in these series. Such type of behaviour can be explained most probably by the participation of $\pi$-electrons of butene diol in these complexes. The magnetic moment $\mu_{\text {eff }}$ (in Bohr magneton) was observed 3.41 -3.49 in ternary complexes of nickel(II) and predict the availability of two unpaired electrons in complexes. The possible structural formulae of these complexes are shown in Figure 1.

Table 2. Stability constants of ternary complexes of nickel(II) $\mathrm{M}=$ nickel(II), $\mathrm{A}=$ histidine, $\mathrm{B}=$ diols $)\left(\mu=0.2, \mathrm{KNO}_{3}, 293 \pm 0.5 \mathrm{~K}\right)$

\begin{tabular}{|c|c|c|c|c|c|c|}
\hline Ligand B & $\log \boldsymbol{\beta}_{\mathbf{M A B}} \pm \mathbf{S D}^{*}$ & $\log \boldsymbol{\beta}_{\mathbf{M A B 2}} \mathbf{S S D}^{*}$ & $\log \boldsymbol{\beta}_{\mathbf{M A 2 B}} \pm \mathbf{S D}^{*}$ & $\log \mathbf{K}_{\mathrm{MAB}} \pm \mathbf{S D}^{*}$ & $\log \mathbf{K}_{\mathrm{MAB2}^{*}} \pm \mathbf{S D}^{*}$ & $\operatorname{logK}_{\mathrm{MA} 2 \mathrm{~B}} \pm \mathbf{S D}^{*}$ \\
\hline Ethane diol & $14.61 \pm 1.65$ & $21.15 \pm 2.05$ & $16.94 \pm 1.77$ & $7.23 \pm 0.29$ & $6.53 \pm 0.25$ & $6.53 \pm 0.33$ \\
\hline Prop-1,2-diol & $15.15 \pm 1.70$ & $21.82 \pm 2.12$ & $22.69 \pm 1.95$ & $4.32 \pm 0.15$ & $6.17 \pm 0.22$ & $6.67 \pm 0.36$ \\
\hline 2-Butene-1,4-diol & $17.64 \pm 1.83$ & $23.81 \pm 2.15$ & $26.59 \pm 2.65$ & $9.25 \pm 0.51$ & $6.15 \pm 0.33$ & $6.17 \pm 0.24$ \\
\hline But-1,3-diol & $15.64 \pm 1.52$ & $22.58 \pm 2.02$ & $23.57 \pm 2.54$ & $8.25 \pm 0.45$ & $6.93 \pm 0.30$ & $6.71 \pm 0.36$ \\
\hline Pent-2,4-diol & $16.17 \pm 1.80$ & $22.60 \pm 2.05$ & $24.72 \pm 2.62$ & $8.79 \pm 0.48$ & $6.42 \pm 0.20$ & $6.42 \pm 0.21$ \\
\hline Hex-1,6-diol & $15.23 \pm 1.41$ & $23.05 \pm 2.21$ & $25.00 \pm 2.72$ & $7.85 \pm 0.39$ & $7.22 \pm 0.32$ & $7.24 \pm 0.40$ \\
\hline
\end{tabular}

SD $=$ standard deviation, *indicates $\mathbf{n}=3$

Table 3. Values of $\Delta \log \mathrm{K}$ and $\log \mathrm{X}$ for ternary complexes of nickel(II) with histidine(A) and $\operatorname{diols}(\mathrm{B})$

\begin{tabular}{|c|c|c|c|c|c|c|}
\hline Ligand B & $\Delta \log _{\mathrm{MAB}} \pm \mathbf{S D}^{*}$ & $\Delta \log \mathbf{K}_{\mathrm{MAB} 2} \pm \mathbf{S D}^{*}$ & $\Delta \log \mathbf{K}_{\mathrm{MA2B}} \pm \mathbf{S D}^{*}$ & $\mathbf{L o g X}_{\mathrm{MAB}} \pm \mathbf{S D}^{*}$ & $\log _{\mathrm{MAB2}} \pm \mathbf{S D}^{*}$ & $\log _{\mathrm{MA2B}} \pm \mathbf{S D}^{*}$ \\
\hline Eth-diol & $0.11 \pm 0.00$ & -3.04 & -0.36 & $4.82 \pm 0.14$ & $14.06 \pm 1.02$ & $20.63 \pm 1.98$ \\
\hline Prop-diol & $0.37 \pm 0.01$ & -3.16 & -0.28 & $5.59 \pm 0.18$ & $11.81 \pm 0.80$ & $20.84 \pm 2.01$ \\
\hline Butene-diol & $2.31 \pm 0.06$ & -3.18 & -0.98 & $8.87 \pm 0.59$ & $14.74 \pm 1.08$ & $23.45 \pm 2.24$ \\
\hline But-diol & $0.86 \pm 0.02$ & -1.85 & -0.91 & $7.07 \pm 0.40$ & $14.57 \pm 1.10$ & $15.14 \pm 0.89$ \\
\hline Pent-diol & $1.62 \pm 0.04$ & -1.41 & -1.10 & $8.22 \pm 0.68$ & $9.92 \pm 0.73$ & $17.18 \pm 1.08$ \\
\hline Hex-diol & $0.78 \pm 0.02$ & -3.22 & -0.70 & $6.87 \pm 0.45$ & $13.20 \pm 0.95$ & $16.70 \pm 1.10$ \\
\hline
\end{tabular}

$\mathrm{SD}=$ standard deviation, *indicates $\mathbf{n}=\mathbf{3}$ 
<smiles>[R]OC1(CO)OC(=O)C(N)Cc2cncn21</smiles>

(A)

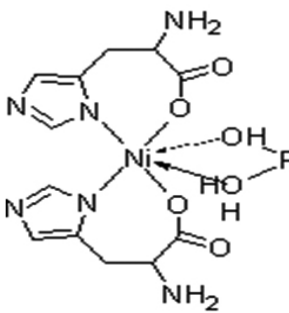

(B)<smiles>[R]O[C@@]1(O)OC(=O)[C@@H](N)Cc2cncn21</smiles>

(C)
Figure 1 Possible structural formulae of ternary complexes of nickel(II) with L-histidine and various diols at different ratios A (1:1:1), B (1:2:1) and C $(1: 1: 2)$.

\section{CONCLUSIONS}

Ternary complexes of nickel(II) with histidine and various diols were successfully synthesized and characterized. The difference in the stability constants of binary and ternary complexes and total enhancement of stability due to mixed ligand complex formation were of greater magnitude in MA $\mathrm{B}$ systems than those in $\mathrm{MAB}_{2}$ systems. The stability of 2-Butene-1,4-diol containing species exhibited the highest stability. It was concluded that the $\pi$-system of the ligands is important for such a great increase in stability. Further studies on characterization of ternary complex of nickel(II) using some sophisticated techniques such X-ray diffraction and nuclear magnetic resonance (NMR) are also required in future.

\section{REFERENCES}

[1] B. Kurzak, D. Kroczweska, Trans. Met. Chem. 18, 295 (1993).

[2] H.A. Azab, A. Hassan, A.M. El-Nady, R.S.A. Azkal, Monat. Furr. Chem. Monthly Chemical. 124, 267 (1993).

[3]. Taha, M.; Khalil, M.M. J. Chem. Engg. Data. 2005, 50, 157-163.

[4] Reddy, P.R.; Rao, K.S. Chem. Biodiver. 2006, 3, 231-244.

[5] Laila, A.R.; Lobna, N.; Ramadan, R. Trans. Met. Chem. 2007, 32, 367373.

[6] Siegel, H. J. Inorg. Nucl. Chem. 1975, 37, 507-509.

[7] Irving, H.; Williams, R.J.P.; Ferret, D.J.; Williams, A.E. J. Chem. Soc. $1954,3494$.

[8] Siegel, H.; Huber, P.P.; Pasternack, R.F. J. Inorg. Chem. 1971, 10, 2226.

[9] Narayan, R.; Day, A.K. Ind. J. Chem. 1976, 14A, 892.

[10] Ahmed, A.; Misra, S.N. Unpublished Observations. Vogel, A.I. (1971).

[11] Siegel, H. Chimica. 1967, 21, 489.

[12] Martin, R.P.; Paris, R.A. Bull. Soc. Chim. France. 1963, 1600.

[13] Siegel, H.; Christoph, F.; Naumann. J. Amer. Chem. Soc. 1976, 98, 730.

[14] Griesser, R.; Siegel, H. Inorg. Chem. 1970, 9, 1238. 